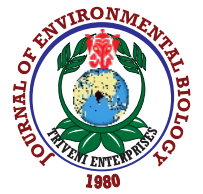

\title{
Impact of foliar application of different nano-fertilizers on soil microbial properties and yield of wheat
}

\author{
R.H. Meena ${ }^{1 *}$, G. Jat ${ }^{1}$ and D. Jain ${ }^{2}$ \\ ${ }^{1}$ Department of Soil Science and Agricultural Chemistry, Rajasthan College of Agriculture, MPUAT, Udaipur-313001, India \\ 2Department of Molecular Biology and Biotechnology, Rajasthan College of Agriculture, MPUAT, Udaipur-313001, India \\ *Corresponding Author Email : ramharim@gmail.com
}

\section{Abstract}

Aim: The present investigation was carried out to study the effect of foliar application nano-fertilizers $\mathrm{P}, \mathrm{K}$ and $\mathrm{Zn}$ on yield, nutrient content and uptake by wheat and soil microbial properties in sub-humid southern plains of Rajasthan.

Methodology: The experiment was laid out in triplicate following randomized block design with fifteen treatments comprising foliar application of different doses of Nano P, K and Zn.

Results: Foliar application of $1^{\text {st }}$ spray of Nano $\mathrm{Zn}$ at 14 days after sowing (DAS) $+2^{\text {nd }}$ spray of Nano $\mathrm{Zn}$ at 28 DAS along with $100 \%$ recommended dose of fertilizers (RDF) significantly $(P=0.05)$ increased yield attributes and nutrient uptake in wheat. The significantly $(P=0.05)$ maximum microbial population (bacteria and fungi) and microbial biomass- $C$ was obtained with $1^{\text {st }}$ spray of Nano $P$ at $14 D A S+2^{\text {nd }}$ spray of Nano P at 28 DAS along with $100 \%$ recommended dose of fertilizers (RDF).

Interpretation: Foliar application of nano fertilizers led to significant improvement of crop productivity of wheat in sub-humid southern plain of Rajasthan. Moreover, the foliar application of nano-fertilizers, i.e., Nano $\mathrm{P}$ also stimulated microbial growth by providing nutrients and directly increased their population in soil.

Key words: Biomass-C, Foliar application, Nanofertilizers, Soil microbial population, Wheat productivity
Imbalance use of chemical fertilizers pesticides and fungicides in soil

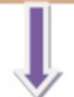

> Deterioration of physical, chemical and biological properties of soil

- Extent of multi-nutrient deficiencies in Indian soils is in the order of $95,94,48,25,41,20,14,8$ and $6 \%$ for $\mathrm{N}, \mathrm{P}, \mathrm{K}, \mathrm{S}, \mathrm{Zn}, \mathrm{B}, \mathrm{Fe}, \mathrm{Mn}$ and $\mathrm{Cu}$, respectively

> Low nutrient use efficiency

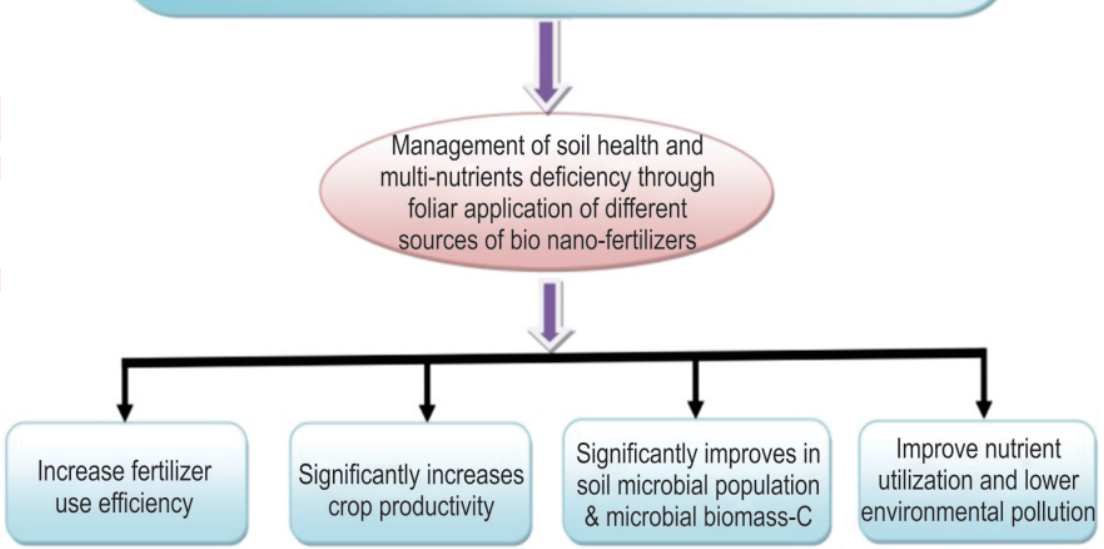
42, 302-308 (2021). 


\section{Introduction}

Wheat (Triticum aestivum L.) is the second most important food grain cereal crop next to rice in India contributing about $35 \%$ of the food grain production covering an area of 29.58 million hectares with annual production of 99.70 million tonnes with a productivity of $3371 \mathrm{~kg} \mathrm{ha}^{-1}$ during 2017-18 (Tiwari et al., 2019). Wheat has significantly contributed towards the success of green revolution and has greatly helped to transform our country from a situation of hand to mouth to being self-sufficient. The increase in crop productivity mainly depends on the fertilizers used to supplement essential nutrients to crop plants. The importance of micronutrients, i.e., $\mathrm{Zn}$ in small amount exerts a positive effect on photosynthesis and thus, improves yield and quality (Hänsch and Mendel, 2009). Macronutrients like N, P, and $\mathrm{K}$ in sufficient quantity throughout the growing season is essential for optimum growth (Haque et al., 2001). Phosphorus, as a constituent of ADP and ATP, plays a key role in energy transformation and storage. It also helps in the assimilation of photosynthates into other metabolites and, hence, acts as an activity zone for $\mathrm{CO}_{2}$ assimilation.

Potassium is an essential nutrient and also the most abundant cation in plants. It plays an essential role in enzyme activation, protein synthesis, photosynthesis, osmoregulation, stomatal movement, energy transfer, phloem transport, cationanion balance and stress resistance (Gul et al., 2015). Likewise, zinc is an essential element for the activities of a number of antioxidant enzymes which maintains the membrane lipids, proteins and nucleic acids in plant cells (Cakmak, 2008). Nanofertilizers deal with the elements in nanometer dimensions (1-100 nm) and at nanoscale, these fertilizers release the nutrients at a slower rate for a longer period, consequently, limiting nutrient loss from the soil and reducing soilgroundwater pollution (Meena et al., 2017). Nano-fertilizers have an important role in the physiological and biochemical processes of crops by increasing the availability of nutrients, which help in enhancing metabolic processes and promoting meristematic activities causing higher apical growth and photosynthetic area (DeRosa et al., 2010). Nanoparticles have unique physico-chemical properties and key potential to boost the plant metabolism (Zulfiqar et al., 2019; Raliya et al., 2018).

The efficiency of nanoparticles is determined by their chemical composition, size, surface covering, reactivity and most important the dose at which they are effective (Jyothi and Hebsur, 2017; Shang et al., 2019). Nano-fertilizers have better nutrient use efficiency due to their better penetration ability and translocation within plant parts (Ghorbanpour et al., 2017; Kopittke et al., 2019), moreover, they prevent undesirable loss of nutrient via direct internalization by crops, and thereby, avoid the interaction of nutrients with soil, water, air and microorganisms (Panpattee et al., 2016). Nanofertilizers also have controlled release and targeted delivery of effective nanoscale ingredients/nutrients and have the ability to improve plant productivity and minimize environmental pollutants (Fatima et al., 2020). Nanofertilizers promote plant growth and crop production by supplying essential nutrients in nano form with high fertilizers use efficiency, ultrahigh absorption due to small size, minimizing potential negative effects associated with over dosage, reducing the frequency of application of fertilizers, low cost due to decline cost of environment protection, maintain soil fertility and soil health thus, it is a new emerging cost effective and eco-friendly alternative to conventional fertilizers. It offers generous visions for sustainable agriculture crop production through improvement of quality food production with minimizing its negative impact on human health as well as environment (Sekhon, 2014). Because of the shortage of arable land, limited water and nutrient resources, the development of agriculture sector is only possible by increasing resource use efficiency with minimum damage to production bed through effective use of modern technologies (Naderi and Shahraki, 2013). The use of nano-fertilizers instead of conventional synthetic fertilizers is a way to release nutrient into soil in controlled and conditional way thus, reducing the loss of nutrients, soil toxicity in soil and maintain sustainability and protection of agriculturally produced food (Arifetal., 2016).

Foliar application is a technique of feeding plants by spraying liquid fertilizers directly to the leaves, which is accompanied with better absorption in the aerial parts (Nasiri et al., 2010; Marzouk et al., 2019). The efficacy of foliar fertilization is higher than that of soil fertilizer application under drought and salinity condition due to supply of required nutrient directly to the leaves, its relatively quick absorption, independence of root activity and soil water availability (Romheld and El-Fouly, 1999). Foliar nano zinc, copper and iron fertilizers application on grain crops increases growth parameters of wheat relative to other fertilizer sources (Ghorbanpour et al., 2017). Hence, looking to the above facts, the present investigation was carried out to study the impact of foliar application of nano-fertilizers on soil microbial population, biomass-C and productivity of wheat in the sub-humid southern plains of Rajasthan.

\section{Materials and Methods}

Study area: The experiment was conducted during rabi 2018-19 at the Instructional Farm, Rajasthan College of Agriculture, Udaipur. The region falls under agro-climatic zone-IVA (Subhumid Southern Plains and Aravalli Hills) of Rajasthan. The climate of the study area is sub-humid with an average minimum and maximum temperature (October-April) ranging between 8.81 to $37.29^{\circ} \mathrm{C}$ during winter season.

Soil analyses: Post-harvest soil samples (0-15 cm depth) collected from each plot after crop harvest were air-dried, ground to pass through a $2 \mathrm{~mm}$ sieve using a wooden pestle and mortar and analyzed for microbial biomass- $\mathrm{C}$ by chloroform fumigationextraction method (Vance et al., 1987). Serial dilution plating method (Vance et al., 1987) was used to enumerate viable counts for soil microbial populations (bacteria and fungi). Plates with serial dilution plating were incubated for 5 days and the number of colonies on different dilution media plates was recorded and the population per gram soil was enumerated. 
Experimental design and treatments: The experiment was laid out in a randomized block design and replicated thrice in the plot size of $2.25 \mathrm{~m} \times 3.0 \mathrm{~m}\left(6.75 \mathrm{~m}^{2}\right)$. The experiment consisted of 15 treatments viz., T1: Control; T2: 100\% RDF;, T3:100\% RDF+ $1^{\text {st }}$ spray of water at 14 DAS; T4:100\% RDF+ $1^{\text {st }}$ spray of Nano P at $14 \mathrm{DAS} ; \mathrm{T}: 100 \% \mathrm{RDF}+1^{\text {st }}$ spray of Nano K at 14 DAS; T6:100\% RDF+ ${ }^{\text {st }}$ spray of Nano Zn at 14 DAS; T7:100\% RDF $+1^{\text {st }}$ spray of Nano P at $14 \mathrm{DAS}+2^{\text {nd }}$ spray of Nano P at 28 DAS; T8:100\% RDF+ $1^{\text {st }}$ spray of Nano K at 14 DAS $+2^{\text {nd }}$ spray of Nano K at $28 \mathrm{DAS} ; \mathrm{T9}: 100 \% \mathrm{RDF}+1^{\text {st }}$ spray of Nano $\mathrm{Zn}$ at $14 \mathrm{DAS}+2^{\text {nd }}$ spray of Nano $\mathrm{Zn}$ at $28 \mathrm{DAS}$; $\mathrm{T} 10: 75 \% \mathrm{RDF}+1^{\text {st }}$ spray of Nano $\mathrm{P}$ at $14 \mathrm{DAS}+2^{\text {nd }}$ spray of Nano $P$ at 28 DAS; T11:75\% RDF+ $1^{\text {st }}$ spray of Nano $\mathrm{K}$ at 14 DAS $+2^{\text {nd }}$ spray of Nano $K$ at $28 \mathrm{DAS} ; \mathrm{T} 12: 75 \% \mathrm{RDF}+1^{\text {st }}$ spray of Nano $\mathrm{Zn}$ at $14 \mathrm{DAS}+2^{\text {nd }}$ spray of Nano $\mathrm{Zn}$ at $28 \mathrm{DAS}$; $\mathrm{T} 13: 50 \% \mathrm{RDF}+1^{\text {st }}$ spray of Nano $\mathrm{P}$ at $14 \mathrm{DAS}+2^{\text {nd }}$ spray of Nano $P$ at 28 DAS; T14: 50\% RDF+ $1^{\text {st }}$ spray of Nano $K$ at 14 DAS $+2^{\text {nd }}$ spray of Nano $K$ at 28 DAS and T15: $50 \% R D F+1^{\text {st }}$ spray of Nano $Z n$ at 14 DAS $+2^{\text {nd }}$ spray of Nano $Z n$ at 28 DAS were applied to wheat var. Raj-3077 in rabi session, 2019-20. The recommended dose of fertilizer were $90 \mathrm{~kg} \mathrm{~N}, 60 \mathrm{~kg} \mathrm{P}_{2} \mathrm{O}_{5}$, $35 \mathrm{~kg} \mathrm{~K}_{2} \mathrm{O}$ and $25 \mathrm{~kg} \mathrm{ZnSO}_{4} \mathrm{ha}^{-1}$ and also other agronomic practices recommended for Zone IV-A were followed as per Package of Practices, Government of Rajasthan. The grains obtained from the produce of individual plot were recorded as grain yield $\mathrm{kg}$ per plot and later it was converted into $\mathrm{kg} \mathrm{ha}^{-1}$.

Application protocol of foliar spray: Foliar sprays were given as $1^{\text {st }}$ application at 14 days after sowing and $2^{\text {nd }}$ application at 28 days after sowing in selected treatments with the help of knapsack sprayer with flat fan nozzle. Nano P and K were applied @ $80 \mathrm{mll}^{-1}$ water while Nano Zn @ $20 \mathrm{mll}^{-1}$ water as per scheduled treatments.

Estimation of yield attributes: The number of effective tillers (ear bearing tillers), yield and yield attributing character were recorded as per standard methods (Singh et al., 2018). The effective tillers (ear bearing tillers) were counted nondestructively from two randomly selected rows in each plot of each replicate and were averaged to number of effective tillers per meter row length in each plot. The grain and straw yield was recorded from the net plot area of each treatment.

Nutrient uptake: Plant samples of grain and straw of wheat collected at harvest were ground in Willey mill to pass through 40 mesh sieves. The samples were used for determination of phosphorus, potassium and zinc content in grain and straw by following standard procedure. The phosphorus content was determined by vanado-molybdo-phosphoric acid yellow colour method (Jackson, 1973) and K content was measured with a flame photometer (Johnson,1959). The zinc content was determined by Atomic absorption spectrophotometrically suggested by Lindsay and Norvell (1978). Nutrient uptake in grain and straw was calculated by multiplying the nutrient concentration (\%) in grain and straw by their respective yield.
Soil microbial properties: Soil samples $(0-15 \mathrm{~cm}$ depth) were collected atharvest of the crop from each treatment plotfor analysis. The samples were stored in plastic bags and taken to the laboratory, where the soil was sieved (2 $\mathrm{mm}$ mesh size), homogenized and stored at $4^{\circ} \mathrm{C}$. The fungal, bacterial and actinomycetes population were estimated by standard plate count method using Marten's for fungi (Martin, 1950), and nutrient agar medium for bacteria and actinomycetes (Allen, 1959). Microbial population was calculated and expressed as number of cells per gram soil. The microbial biomass carbon (MBC) was measured by fumigation-extraction method and calculated by the following formula: Biomass $\mathrm{C}=\mathrm{EC} / \mathrm{kEc}$ where, $\mathrm{kEcis} 0.38$ (Vance etal., 1987).

Statistical analysis: All obtained data were subjected to statistically analysis of variance (ANOVA) as described by Panse and Sukhatme (1985). The critical difference was worked out at 5 percent $(0.05)$ probability levels.

\section{Results and Discussion}

Application of foliar spray of nano-fertilizer enhanced the number of effective tillers per meter row length, grain and straw yield of wheat significantly (Table 1). The maximum number of effective tillers per meter row length (80.16), grain yield (5565.20 $\left.\mathrm{kg} \mathrm{ha}^{-1}\right)$ and straw yield $\left(7135.46 \mathrm{~kg} \mathrm{ha}^{-1}\right)$ were observed under the treatment T9 $\left(100 \% \mathrm{RDF}+1^{\text {st }}\right.$ spray of Nano $\mathrm{Zn}$ at $14 \mathrm{DAS}+2^{\text {nd }}$ spray of Nano Zn at $28 \mathrm{DAS})$ followed by $\mathrm{T} 12\left(75 \% \mathrm{RDF}+1^{\text {st }}\right.$ spray of Nano $Z n$ at 14 DAS $+2^{\text {nd }}$ spray of Nano $Z n$ at 28 DAS), T10 $\left(75 \% \mathrm{RDF}+1^{\text {st }}\right.$ spray of Nano $\mathrm{P}$ at $14 \mathrm{DAS}+2^{\text {nd }}$ spray of Nano $\mathrm{P}$ at $28 \mathrm{DAS}), \mathrm{T} 11\left(75 \% \mathrm{RDF}+1^{\text {st }}\right.$ spray of Nano Kat $14 \mathrm{DAS}+2^{\text {nd }}$ spray of Nano K at 28 DAS) as compared to control. Nano fertilizers or nano-encapsulated nutrients have properties that are effective to crops, release the nutrients on-demand, controlled release of chemical fertilizers that regulate plant growth and enhanced target activity (Nair et al., 2010).

Foliar application is a quick and effective treatment for plant nutrition, as it allows rapid uptake of nutrients during the fast-growing period of crop, especially soil deficient in available soil nutrients (Wojtkowiak et al., 2014). It was evident from the present study that foliar application of Nano P, K and Zn manipulates growth parameters of wheat, resulting in significant improvement in yield and yield related components. The enhanced growth may be attributed to increased growth hormone and photosynthetic activities due to applications of nanofertilizers. Moreover, the application of nano $\mathrm{Zn}$ enhances the metabolic processes of plants and photosynthesis, resulted increase flowering and grain formation, which ultimately increased the yield attributes. Several research findings have reported that nanofertlizers promote photosynthesis and plant growth (Wu, 2013; Fatima et al., 2020). Nano-fertilizers viz., nano-NPK are considered as biological pumps of the plants to promote nutrients and water absorption in crop plants (Ma et al., 2009). The results obtained in the present study collaborates with the previous reports where foliar spray of nano-fertilizers increased the yield and yield components of wheat crop (Zain et 
Table 1: Effect of foliar application of nano-fertilizers on yield attributes and yield of wheat

\begin{tabular}{|c|c|c|c|c|}
\hline \multicolumn{2}{|c|}{ Treatments } & \multirow{2}{*}{$\begin{array}{l}\text { Number of effective } \\
\text { tillers per meter } \\
\text { row length } \\
55.13\end{array}$} & \multirow{2}{*}{$\begin{array}{l}\begin{array}{l}\text { Grain yield } \\
\left.\text { (kg ha }^{-1}\right)\end{array} \\
3153.22\end{array}$} & \multirow{2}{*}{$\begin{array}{l}\begin{array}{l}\text { Straw yield } \\
\left.\text { (kg ha }^{-1}\right)\end{array} \\
4048.18\end{array}$} \\
\hline $\mathrm{T}_{1}:$ & Control & & & \\
\hline $\mathrm{T}_{2}:$ & RDF & 66.18 & 4007.81 & 5142.03 \\
\hline $\mathrm{T}_{3}:$ & $100 \% R D F+1^{\text {st }}$ spray of water at 14 DAS & 68.17 & 4260.16 & 5464.98 \\
\hline $\mathrm{T}_{4}$ : & $100 \% R D F+1^{\text {st }}$ spray of Nano $P$ at 14 DAS & 71.10 & 4456.84 & 5716.73 \\
\hline $\mathrm{T}_{5}$ : & $100 \% R D F+1^{\text {st }}$ spray of Nano $\mathrm{K}$ at $14 \mathrm{DAS}$ & 71.02 & 4405.25 & 5650.70 \\
\hline $\mathrm{T}_{6}$ : & $100 \% R D F+1^{\text {st }}$ spray of Nano $Z n$ at 14 DAS & 72.01 & 4678.98 & 6001.09 \\
\hline $\mathrm{T}_{7}:$ & $100 \% R D F+1^{\text {st }}$ spray of Nano $P$ at 14 DAS $+2^{\text {nd }}$ spray of Nano $P$ at 28 DAS & 74.15 & 4987.21 & 6395.59 \\
\hline $\mathrm{T}_{8}:$ & $100 \% R D F+1^{\text {st }}$ spray of Nano $\mathrm{K}$ at $14 \mathrm{DAS}+2^{\text {nd }}$ spray of Nano $\mathrm{K}$ at $28 \mathrm{DAS}$ & 74.01 & 4895.69 & 6278.54 \\
\hline $\mathrm{T}_{9}:$ & $100 \% R D F+1^{\text {st }}$ spray of Nano $Z n$ at $14 D A S+2^{\text {nd }}$ spray of Nano $Z n$ at 28 DAS & 80.16 & 5565.20 & 7135.46 \\
\hline$T_{10}:$ & $75 \% R D F+1^{\text {st }}$ spray of Nano $P$ at 14 DAS $+2^{\text {nd }}$ spray of Nano $P$ at 28 DAS & 77.01 & 5114.57 & 6557.26 \\
\hline$T_{11}:$ & $75 \% R D F+1^{\text {st }}$ spray of Nano K at 14 DAS $+2^{\text {nd }}$ spray of Nano K at 28 DAS & 76.35 & 5100.97 & 6541.29 \\
\hline $\mathrm{T}_{12}$ : & $75 \% R D F+1^{\text {st }}$ spray of Nano $Z n$ at 14 DAS $+2^{\text {nd }}$ spray of Nano $Z n$ at 28 DAS & 79.47 & 5510.50 & 7066.37 \\
\hline $\mathrm{T}_{13}$ : & $50 \% R D F+1^{\text {st }}$ spray of Nano $P$ at $14 \mathrm{DAS}+2^{\text {nd }}$ spray of Nano $P$ at 28 DAS & 62.74 & 3757.34 & 4821.43 \\
\hline$T_{14}:$ & $50 \% R D F+1^{\text {st }}$ spray of Nano $K$ at 14 DAS $+2^{\text {nd }}$ spray of Nano $K$ at 28 DAS & 61.36 & 3701.52 & 4749.93 \\
\hline $\mathrm{T}_{15}:$ & $50 \% R D F+1^{\text {st }}$ spray of Nano $Z n$ at $14 \mathrm{DAS}+2^{\text {nd }}$ spray of Nano $\mathrm{Zn}$ at $28 \mathrm{DAS}$ & 64.58 & 3898.23 & 5001.75 \\
\hline \multicolumn{2}{|r|}{ 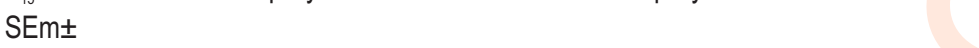 } & 2.13 & 131.66 & 170.84 \\
\hline \multicolumn{2}{|c|}{$C D(P=0.05)$} & 6.16 & 381.42 & 494.91 \\
\hline
\end{tabular}

$100 \%$ RDF= Recommended dose of fertilizer- $90 \mathrm{~kg} \mathrm{~N}, 60 \mathrm{~kg} \mathrm{P}_{2} \mathrm{O}_{5}, 35 \mathrm{~kg} \mathrm{~K}_{2} \mathrm{O}$ and $25 \mathrm{~kg} \mathrm{ZnSO}_{4}$ ha $^{-1} ; 75 \%$ RDF= Recommended dose of fertilizer- $67.5 \mathrm{~kg}$ $\mathrm{N}, 45 \mathrm{~kg} \mathrm{P}_{2} \mathrm{O}_{5}, 26.25 \mathrm{~kg} \mathrm{~K}_{2} \mathrm{O}$ and $18.75 \mathrm{~kg} \mathrm{ZnSO}_{4}$ ha ${ }^{-1}$ and $50 \%$ RDF= Recommended dose of fertilizer- $45 \mathrm{~kg} \mathrm{~N}, 30 \mathrm{~kg} \mathrm{P}_{2} \mathrm{O}_{5}, 17.50 \mathrm{~kg} \mathrm{~K} 2 \mathrm{O}$ and $12.5 \mathrm{~kg}$ $\mathrm{ZnSO}_{4} \mathrm{ha}^{-1}$

Table 2: Effect of foliar application of nano-fertilizers on P, Kand Zn uptake by grain and straw of wheat

\begin{tabular}{|c|c|c|c|c|c|c|}
\hline \multirow[t]{2}{*}{ Treatments } & \multicolumn{2}{|c|}{$\begin{array}{l}\text { Phosphorus } \\
\left(\mathrm{kg} \mathrm{ha}^{-1}\right)\end{array}$} & \multicolumn{2}{|c|}{$\begin{array}{l}\text { Potassium } \\
\left(\mathrm{kg} \mathrm{ha}^{-1}\right)\end{array}$} & \multicolumn{2}{|c|}{$\underset{\left(\mathrm{g} \mathrm{ha} \mathrm{a}^{-1}\right)}{\text { Zinc }}$} \\
\hline & Grain & Straw & Grain & Straw & Grain & Straw \\
\hline $\mathrm{T}_{1}$ : Control & 8.35 & 6.68 & 14.75 & 53.48 & 145.00 & 121.95 \\
\hline $\mathrm{T}_{2}: \mathrm{RDF}$ & 11.62 & 9.87 & 19.68 & 70.76 & 200.75 & 183.31 \\
\hline $\mathrm{T}_{3}: \quad 100 \% \mathrm{RDF}+1^{\text {st }}$ spray of water at $14 \mathrm{DAS}$ & 13.25 & 11.20 & 21.52 & 76.78 & 217.32 & 197.55 \\
\hline $\mathrm{T}_{4}: \quad 100 \% \mathrm{RDF}+1^{\text {st }}$ spray of Nano $\mathrm{P}$ at $14 \mathrm{DAS}$ & 14.71 & 12.29 & 22.68 & 80.66 & 232.06 & 212.72 \\
\hline $\mathrm{T}_{5}: \quad 100 \% \mathrm{RDF}+1^{\text {st }}$ spray of Nano $\mathrm{K}$ at $14 \mathrm{DAS}$ & 13.87 & 11.47 & 24.00 & 82.97 & 229.14 & 209.97 \\
\hline $\mathrm{T}_{6}: \quad 100 \% \mathrm{RDF}+1^{\text {st }}$ spray of Nano $\mathrm{Zn}$ at $14 \mathrm{DAS}$ & 14.65 & 12.05 & 23.73 & 84.41 & 271.74 & 245.81 \\
\hline $\mathrm{T}_{7}: \quad 100 \% \mathrm{RDF}+1^{\text {st }}$ spray of Nano $\mathrm{P}$ at $14 \mathrm{DAS}+2^{\text {nd }}$ spray of Nano $\mathrm{P}$ at $28 \mathrm{DAS}$ & 16.80 & 14.13 & 25.78 & 90.83 & 269.77 & 249.77 \\
\hline $\mathrm{T}_{8}: \quad 100 \% \mathrm{RDF}+1^{\text {st }}$ spray of Nano $\mathrm{K}$ at $14 \mathrm{DAS}+2^{\text {nd }}$ spray of Nano $\mathrm{K}$ at $28 \mathrm{DAS}$ & 15.59 & 13.26 & 27.13 & 93.55 & 265.51 & 244.91 \\
\hline $\mathrm{T}_{9}: \quad 100 \% R D F+1^{\text {st }}$ spray of Nano $\mathrm{Zn}$ at $14 \mathrm{DAS}+2^{\text {nd }}$ spray of Nano $\mathrm{Zn}$ at $28 \mathrm{DAS}$ & 17.58 & 14.84 & 28.54 & 101.10 & 330.32 & 305.88 \\
\hline $\mathrm{T}_{10}: 75 \% \mathrm{RDF}+1^{\text {st }}$ spray of Nano $\mathrm{P}$ at $14 \mathrm{DAS}+2^{\text {nd }}$ spray of Nano $\mathrm{P}$ at $28 \mathrm{DAS}$ & 17.17 & 14.35 & 26.01 & 92.15 & 275.66 & 252.83 \\
\hline $\mathrm{T}_{11}: 75 \% \mathrm{RDF}+1^{\text {st }}$ spray of Nano $\mathrm{K}$ at $14 \mathrm{DAS}+2^{\text {nd }}$ spray of Nano $\mathrm{K}$ at $28 \mathrm{DAS}$ & 15.20 & 12.48 & 28.10 & 96.79 & 272.48 & 248.75 \\
\hline $\mathrm{T}_{12}: 75 \% \mathrm{RDF}+1^{\text {st }}$ spray of Nano $\mathrm{Zn}$ at $14 \mathrm{DAS}+2^{\text {nd }}$ spray of Nano $\mathrm{Zn}$ at $28 \mathrm{DAS}$ & 16.26 & 13.43 & 27.72 & 99.00 & 324.28 & 298.56 \\
\hline $\mathrm{T}_{13}: 50 \% R D F+1^{\text {st }}$ spray of Nano $\mathrm{P}$ at $14 \mathrm{DAS}+2^{\text {nd }}$ spray of Nano $\mathrm{P}$ at $28 \mathrm{DAS}$ & 11.47 & 9.55 & 18.35 & 65.68 & 182.74 & 161.94 \\
\hline $\mathrm{T}_{14}: 50 \% \mathrm{RDF}+1^{\text {st }}$ spray of Nano $\mathrm{K}$ at $14 \mathrm{DAS}+2^{\text {nd }}$ spray of Nano $\mathrm{K}$ at $28 \mathrm{DAS}$ & 10.55 & 8.69 & 19.51 & 68.94 & 178.53 & 156.80 \\
\hline $\mathrm{T}_{15}: 50 \% R D F+1^{\text {st }}$ spray of Nano $\mathrm{Zn}$ at $14 \mathrm{DAS}+2^{\text {nd }}$ spray of Nano $\mathrm{Zn}$ at $28 \mathrm{DAS}$ & 10.96 & 9.01 & 18.92 & 68.04 & 227.50 & 209.84 \\
\hline SEm \pm & 0.615 & 0.389 & 0.942 & 3.05 & 13.54 & 9.69 \\
\hline$C D(P=0.05)$ & 1.78 & 1.12 & 2.72 & 8.83 & 39.22 & 28.09 \\
\hline
\end{tabular}

$100 \%$ RDF= Recommended dose of fertilizer- $90 \mathrm{~kg} \mathrm{~N}, 60 \mathrm{~kg} \mathrm{P}_{2} \mathrm{O}_{5}, 35 \mathrm{~kg} \mathrm{~K}_{2} \mathrm{O}$ and $25 \mathrm{~kg} \mathrm{ZnSO}_{4}$ ha $^{-1} ; 75 \%$ RDF= Recommended dose of fertilizer- $67.5 \mathrm{~kg}$ $\mathrm{N}, 45 \mathrm{~kg} \mathrm{P}_{2} \mathrm{O}_{5}, 26.25 \mathrm{~kg} \mathrm{~K}_{2} \mathrm{O}$ and $18.75 \mathrm{~kg} \mathrm{ZnSO}_{4}$ ha $^{-1}$ and $50 \%$ RDF= Recommended dose of fertilizer- $45 \mathrm{~kg} \mathrm{~N}, 30 \mathrm{~kg} \mathrm{P} \mathrm{O}_{5}, 17.50 \mathrm{~kg} \mathrm{~K} \mathrm{O}_{2}$ and $12.5 \mathrm{~kg}$ $\mathrm{ZnSO}_{4} \mathrm{ha}^{-1}$ 
Table 3: Effect of foliar application of nano-fertilizers on microbial population and biomass carbon in post harvest soil

\begin{tabular}{|c|c|c|c|}
\hline \multirow{2}{*}{ Treatments } & \multicolumn{2}{|c|}{ Microbial population } & \multirow{2}{*}{$\begin{array}{c}\text { Microbial } \\
\text { biomass-C } \\
\left(\mathrm{mg} \mathrm{kg}^{-1}\right)\end{array}$} \\
\hline & Bacteria $\left(X 10^{6}\right)$ & Fungi $\left(X 10^{4}\right)$ & \\
\hline $\mathrm{T}_{1}$ : Control & 52.01 & 15.02 & 221.21 \\
\hline $\mathrm{T}_{2}: \quad \mathrm{RDF}$ & 61.25 & 19.36 & 232.36 \\
\hline $\mathrm{T}_{3}: \quad 100 \% \mathrm{RDF}+1^{\text {st }}$ spray of water at $14 \mathrm{DAS}$ & 67.36 & 25.21 & 245.29 \\
\hline $\mathrm{T}_{4}: \quad 100 \% \mathrm{RDF}+1^{\text {st }}$ spray of Nano $\mathrm{P}$ at $14 \mathrm{DAS}$ & 71.65 & 28.54 & 249.01 \\
\hline $\mathrm{T}_{5}: \quad 100 \% \mathrm{RDF}+1^{\text {st }}$ spray of Nano $\mathrm{K}$ at $14 \mathrm{DAS}$ & 70.24 & 27.52 & 248.22 \\
\hline $\mathrm{T}_{6}: \quad 100 \% \mathrm{RDF}+1^{\text {st }}$ spray of Nano $\mathrm{Zn}$ at $14 \mathrm{DAS}$ & 69.11 & 26.85 & 247.54 \\
\hline $\mathrm{T}_{7}: \quad 100 \% \mathrm{RDF}+1^{\text {st }}$ spray of Nano $\mathrm{P}$ at $14 \mathrm{DAS}+2^{\text {nd }}$ spray of Nano $\mathrm{P}$ at $28 \mathrm{DAS}$ & 78.54 & 34.25 & 259.33 \\
\hline $\mathrm{T}_{8}: \quad 100 \% \mathrm{RDF}+1^{\text {st }}$ spray of Nano $\mathrm{K}$ at $14 \mathrm{DAS}+2^{\text {nd }}$ spray of Nano $\mathrm{K}$ at $28 \mathrm{DAS}$ & 77.21 & 33.42 & 257.14 \\
\hline $\mathrm{T}_{9}: \quad 100 \% \mathrm{RDF}+1^{\text {st }}$ spray of Nano $\mathrm{Zn}$ at $14 \mathrm{DAS}+2^{\text {nd }}$ spray of Nano $\mathrm{Zn}$ at $28 \mathrm{DAS}$ & 76.36 & 32.12 & 256.41 \\
\hline $\mathrm{T}_{10}: \quad 75 \% \mathrm{RDF}+1^{\text {st }}$ spray of Nano $\mathrm{P}$ at $14 \mathrm{DAS}+2^{\text {nd }}$ spray of Nano $\mathrm{P}$ at $28 \mathrm{DAS}$ & 76.51 & 31.41 & 254.25 \\
\hline $\mathrm{T}_{11}: \quad 75 \% \mathrm{RDF}+1^{\text {st }}$ spray of Nano $\mathrm{K}$ at $14 \mathrm{DAS}+2^{\text {nd }}$ spray of Nano $\mathrm{K}$ at $28 \mathrm{DAS}$ & 75.25 & 30.65 & 253.03 \\
\hline $\mathrm{T}_{12}: \quad 75 \% \mathrm{RDF}+1^{\text {st }}$ spray of Nano $\mathrm{Zn}$ at $14 \mathrm{DAS}+2^{\text {nd }}$ spray of Nano $\mathrm{Zn}$ at $28 \mathrm{DAS}$ & 74.26 & 29.54 & 252.21 \\
\hline $\mathrm{T}_{13}: \quad 50 \% \mathrm{RDF}+1^{\text {st }}$ spray of Nano $\mathrm{P}$ at $14 \mathrm{DAS}+2^{\text {nd }}$ spray of Nano $\mathrm{P}$ at $28 \mathrm{DAS}$ & 64.28 & 21.12 & 238.21 \\
\hline $\mathrm{T}_{14}: \quad 50 \% \mathrm{RDF}+1^{\text {st }}$ spray of Nano $\mathrm{K}$ at $14 \mathrm{DAS}+2^{\text {nd }}$ spray of Nano $\mathrm{K}$ at $28 \mathrm{DAS}$ & 62.22 & 20.36 & 237.25 \\
\hline $\mathrm{T}_{15}: \quad 50 \% \mathrm{RDF}+1^{\text {st }}$ spray of Nano $\mathrm{Zn}$ at $14 \mathrm{DAS}+2^{\text {nd }}$ spray of Nano $\mathrm{Zn}$ at $28 \mathrm{DAS}$ & 62.02 & 20.01 & 236.53 \\
\hline SEm \pm & 2.62 & 1.01 & 4.81 \\
\hline $\mathrm{CD}(\mathrm{P}=0.05)$ & 7.59 & 2.94 & 13.94 \\
\hline
\end{tabular}

$100 \%$ RDF= Recommended dose of fertilizer- $90 \mathrm{~kg} \mathrm{~N}, 60 \mathrm{~kg} \mathrm{P}_{2} \mathrm{O}_{5}, 35 \mathrm{~kg} \mathrm{~K}_{2} \mathrm{O}$ and $25 \mathrm{~kg} \mathrm{ZnSO}_{4} \mathrm{ha}^{-1} ; 75 \%$ RDF= Recommended dose of fertilizer- $67.5 \mathrm{~kg}$ $\mathrm{N}, 45 \mathrm{~kg} \mathrm{P}_{2} \mathrm{O}_{5}, 26.25 \mathrm{~kg} \mathrm{~K}_{2} \mathrm{O}$ and $18.75 \mathrm{~kg} \mathrm{ZnSO}_{4}$ ha $^{-1}$ and $50 \%$ RDF= Recommended dose of fertilizer- $45 \mathrm{~kg} \mathrm{~N}, 30 \mathrm{~kg} \mathrm{P} \mathrm{O}_{5}, 17.50 \mathrm{~kg} \mathrm{~K} \mathrm{O}_{2}$ and $12.5 \mathrm{~kg}$ $\mathrm{ZnSO}_{4} \mathrm{ha}^{-1}$

al., 2015; Mer and Ama, 2014). Similarly in chickpea, foliar spray of NPK nano-fertilizers also increased the yield and yield components as a result of increased activities of growth hormone and enhanced metabolic processes, which tend to increase flowering and grain formation (Drostkar et al., 2016). Similar results were also reported by Abdel-Aziz et al. (2018) who found that foliar spray of nano NPK increased the growth and yield of wheat. Marzouk et al. (2019) also reported that foliar application of zinc nano-fertilizer enhanced the vegetative growth and yield attributes, yield and nutritional value of snap bean significantly compared with other nano micronutrients (Feand Mn).

Application of foliar spray of nano-fertilizer significantly enhanced the phosphorus, potassium and zinc uptake by wheat (Table 2). The maximum $\mathrm{P}, \mathrm{K}$ and $\mathrm{Zn}$ uptake by grain and straw (17.58 and $14.84 \mathrm{~kg} \mathrm{ha}^{-1}, 28.54$ and $101.10 \mathrm{~kg} \mathrm{ha}^{-1}$ and 330.32 and $305.88 \mathrm{~g} \mathrm{ha}^{-1}$, respectively) were recorded under the treatment T9 $\left(100 \%\right.$ RDF $+1^{\text {st }}$ spray of Nano Zn at 14 DAS $+2^{\text {nd }}$ spray of Nano Zn at 28 DAS) followed by T10 (75\% RDF $+1^{\text {st }}$ spray of Nano $P$ at 14 DAS $+2^{\text {nd }}$ spray of Nano $P$ at 28 DAS $), T 7(100 \%$ $\mathrm{RDF}+1^{\text {st }}$ spray of Nano $\mathrm{P}$ at $14 \mathrm{DAS}+2^{\text {nd }}$ spray of Nano $\mathrm{P}$ at 28 DAS), T8 $\left(75 \%\right.$ RDF $+1^{\text {st }}$ spray of Nano K at $14 \mathrm{DAS}+2^{\text {nd }}$ spray of Nano Kat 28 DAS $)$ and T12 (75\% RDF $+1^{\text {st }}$ spray of Nano Zn at 14 $\mathrm{DAS}+2^{\text {nd }}$ spray of Nano $\mathrm{Zn}$ at $28 \mathrm{DAS}$ ) as compared to control. It may be due to better release and uptake of phosphorus, potassium and zinc from nano-fertilizers than conventional fertilizers. Soliman et al. (2016) concluded that the application of nano-phosphatic fertilizer exposes the plant nutrient (NPK) to larger surface area than can enhance the fixation of plant nutrient of nano-particle, minimizing the loss at later stages of crop growth when the plant requires it. Kaviani et al. (2016) observed that foliar application of nano-fertilizers had significant positive effects on leaf $\mathrm{N}, \mathrm{P}, \mathrm{K}$ contents in heated plants as compared to control. Kumar et al. (2014) and Shrivastava et al. (2017) also confirm the findings of the present study. Sarkar et al. (2013) observed that application of nano-phosphatic fertilizer significantly increased the phosphorus concentration and uptake in pearl millet. Hanif et al. (2015) reported that phosphorus uptake per plant was increased five-folds with respect to the control due to direct entry of nano-particles in the plant being able to trigger metabolic activity contributing and enhanced exudation leading to acidification. Subsequently, desorption of $\mathrm{Po}_{4}{ }^{3-}$ occurs through a ligand exchange reaction upon plant root exudation, possibly altering the adsorption desorption equilibrium and releasing phosphorus into soil solution which is readily available for uptake. Hussien et al. (2015) observed that synthetic apatite nanoparticles can hypothetically supply sufficient phosphorus to crops throughout during growth period.

The present results are in close conformity with Kaviani et al. (2016) and Togas et al. (2017). Use of nano-fertilizer @1000 $\mathrm{mg} \mathrm{l}^{-1}$ helps to increase the concentration of micronutrients in roots and shoots of lettuce plants as reflected in plant growth (Roosta et al., 2017). These results indicate that nano-composite NPK fertilizers mitigate the increase in plasma membrane permeability and cell mortality under the effect of nano-particles in 
wheat plants (Du et al., 2011). Similar results were reported by Wang et al. (2013) in watermelon plant after foliar uptake of nanocomposite. Application of foliar spray of nano-fertilizer significantly increased the soil microbial population (bacteria and fungi) and microbial biomass-C in soil after crop harvest (Table 3). A significant maximum microbial count of bacteria $\left(78.54 \times 10^{6}\right)$, fungi $\left(34.25 \times 10^{4}\right)$ and microbial biomass-C (259.33 $\left.\mathrm{mg} \mathrm{kg}^{-1}\right)$ was obtained under the treatment $100 \% \mathrm{RDF}+1^{\text {st }}$ spray of Nano $\mathrm{P}$ at $14 \mathrm{DAS}+2^{\text {nd }}$ spray of Nano P at $28 \mathrm{DAS}$ followed by $100 \%$ RDF + $1^{\text {st }}$ spray of Nano K at $14 \mathrm{DAS}+2^{\text {nd }}$ spray of Nano K at $28 \mathrm{DAS}$, $100 \%$ RDF $+1^{\text {st }}$ spray of Nano $Z n$ at 14 DAS $+2^{\text {nd }}$ spray of Nano $Z n$ at 28 DAS as compared to control. Nano-fertilizers stimulated the growth of microbes by providing nutrients in available soluble forms and directly increased the population.

Increased availability of $\mathrm{N}, \mathrm{P}, \mathrm{K}$ and $\mathrm{Zn}$ which is preferentially assimilated by microorganisms (Paul and Clark, 1996), but normally limited in soil, enables increase in activity of microbial biomass. Increased and toxic concentration of nanomaterial applications poses a threat to soil microbial communities (Rajput et al., 2018). However, in the present study, the application of nano-fertilizers appears to be safer and due to proper availability of nutrients improved both plant and microbial biomass. Microbial activity of a soil system is affected by anthropogenic activities such as indiscriminate use of chemical. Microbial population decreases with increase in levels of contaminants (Xie et al., 2016). The enhancement in microbial population and activity in rhizosphere may also enhance nutrient mobilization and availability of nutrients for plants uptake (Pandey et al., 2010).

Based on the above results, it can be concluded that foliar application of nano-fertilizers not only improves the yield but also improves the soil microbial population and microbial biomass- $\mathrm{C}$ in the post harvest status of soil. Nano-fertilizers can serve as an efficient nutrient delivery system thereby reducing the quantity of nutrients required, soil enzymes are considered as the best indicator of microbial diversity of a soil and increases the effectiveness of applied nutrients as well as nutrients in the labile pool. The results reported here bring to light the possibility of using nano-fertilizers to deliver essential nutrients to crop plants more safely and efficiently in environmentally favourable manner.

\section{Acknowledgment}

The authors acknowledge the financial support received from Indian Farmers Fertilizer Cooperative (IFFCO), New Delhi.

\section{Add-on Information}

Authors' contribution: R.H. Meena: Conceived and designed the experiments; G. Jat: Experimental Research; D. Jain: Manuscript writing and data analysis.

Research content: The research content is original and has not been published elsewhere

Ethical approval: NotApplicable

Conflict of interest: The authors declare that there is no conflict of interest.

\section{Data from other sources: NotApplicable}

Consent to publish: All authors agree to publish the paper in Journal of Environmental Biology.

\section{References}

Abdel-Aziz H.M.M, N.A.H. Mohammed and M.O. Aya: Effect of foliar application of nano chitosan NPK fertilizer on the chemical composition of wheat grains. Egypt. J. Bot., 58, 87 - 95 (2018).

Allen, O.N.: Experiments in Soil Bacteriology. $3^{\text {rd }}$ Edn., Burgess Publishing Co., Minneapolis, USA(1959).

Arif, N., V. Yadav, S. Singh, S. Singh, R.K. Mishra, S. Sharma, N. K. Dubey, D.K. Tripathi and D.K. Chauhan: Current trend of engineered nanoparticles (ENPs) in sustainable agriculture. An Overview. J. Environ. Anal. Toxicol., 6, 1-5 (2016).

Cakmak, I.: Enrichment of cereal grains with zinc: Agronomic or genetic biofortification? Plant Soil, 302,1-17(2008).

DeRosa, M.C., C. Monreal, M. Schnitzer, R. Walsh and Y Sultan: Nanotechnology in fertilizers. Nat. Nanotechnol., 5, 91 (2010).

Drostkar, E., R. Talebi and H. Kanouni: Foliar application of Fe, Zn and NPK nano-fertilizers on seed yield and morphological traits in chickpea under rainfed condition. J. Res. Ecol., 4, 221-228 (2016).

Du, S.Y., R. Ji, J. Zhu, J. Wu and H. Guo: $\mathrm{TiO}_{2}$ and $\mathrm{ZnO}$ nanoparticles negatively affect wheat growth and soil enzyme activities in agricultural soil. J. Environ. Monit., 13, 822-828 (2011).

Fatima, F., A. Hashim and S. Anees: Efficacy of nanoparticles as nanofertilizer production: A review. Environ. Sci. Pollut. Res., 28, 1292-1303 (2021).

Ghorbanpour, M., K. Manika and A. Varma: Nanoscience and Plant-Soil Systems. Springer International Publishing (2017).

Gul, S., M.H. Khan, B.A. Khanday and S. Nabi: Effect of sowing methods and NPK levels on growth and yield of rainfed maize (Zea mays L.). Hindawi Publishing Corporation, Scientifica, Vol. 15, https: //doi.org/10.1155/2015/198575(2015).

Hanif, H.U., M. Arshad, M.A. Ali, N. Ahmed and I.A. Qazi: Phytoavailability of phosphorus to Lactuca sativa in response to soil applied $\mathrm{TiO}_{2}$ nanoparticles. Pak. J. Agric. Sci., 52, 177-182 (2015).

Hänsch, R. and R. Mendel: Physiological functions of mineral micronutrients (Cu, Zn, Mn, Fe, Ni, Mo, B, Cl). Curr. Opin. Plant. Biol., 12, 259-266 (2009).

Haque, M.M., A. Hamid and N.I. Bhuiyan: Nutrient uptake and productivity as affected by nitrogen and potassium application levels $\mathrm{N}$ maize/sweet potato intercropping system. Korean J. Crop Sci., 46, 1-5 (2001).

Hussien, M.M., M.E.A. Soad and W.M. Haggag: Response of mineral status to nano-fertilizer and moisture stress during different growth stages of cotton plants. Int. J. Chem. Tech. Res., 8, 643-650 (2015).

Jackson, M.L.: Soil Chemical Analysis. Prentice Hall of India Pvt. Ltd., New Delhi (1973).

Johnson, C.M. and A. Ulrich: Analytical method for use in plant analysis. Calif. Agri. Expt. Sta. Bull., 54, 766 (1959).

Jyothi, T.V. and N.S. Hebsur: Effect of nano-fertilizers on growth and yield 
of selected cereals -A review. Agric. Rev., 38, 112-120 (2017).

Kaviani, B., M.V.F. Ghaziani and N. Negahdar: Effect of application methods and different concentrations of biologic nano-fertilizer, especial for ornamental plants on some morphological, physiological and proliferation traits and enhancing the quality of Buxus Hyrcana Pojark. Int. J. Adv. Sci. Eng. Tech., 2, 206-212 (2016).

Kopittke, P.M., E. Lombi, P. Wang, J.K. Schjoerring and S. Husted: Nanomaterials as fertilizers for improving plant mineral nutrition and environmental outcomes. Environ. Sci. Nano., 6, 3513-3524 (2019).

Kumar, P., R. Singh, A. Singh, D. Paliwal and S. Kumar: Integrated nutrient management in pearl millet (Pennisetum glaucum) - wheat (Triticum aestivum) cropping sequence in semi-arid condition of India. Int. J. Agric. Sci., 10, 96 - 101 (2014).

Lindsay, W.L. and W.L. Norvell: Development of a DTPA soil test for Zn, Fe, Mn and Cu. Soil Sci. Soc. Am. J., 42, 421-442 (1978).

$\mathrm{Ma}$, J., J. Liu and Z.M. Zhang: Application study of carbon nano-fertilizer on growth of winter wheat. Humic Acid, 2,14-20 (2009).

Martin, J.P.: Use of acid rose Bengal and streptomycin in the plate method for estimating soil fungi. Soil Sci., 69, 215-232 (1950)

Marzouk, N.M., H.A. Abd-Alrahman, EL-Tanahy and S.H. Mohmouud: Impact of foliar spraying of nano micronutrient fertilizers on the growth, yield, physical quality, and nutritional value of two snap bean cultivars in sandy soils. Bull. Natl. Res. Cent., 43, 84 (2019).

Meena, S., C. Gautam, P. Patidar, M. Meena, G. Prakasha and G. Vishwajith: Nano fertilizers is a new way to increase nutrients use efficiency in crop production. Int. J. Agric. Sci., 9, 3831-3833 (2017)

Mer, M. and E.H.E. Ama: Effect of Cu, Fe, Mn, Zn foliar application on productivity and quality of some wheat cultivars (Triticum aestivum L.). J. Agri. FoodAppl. Sci., 2, 283-291 (2014).

Naderi, M. and A. Shahraki. Nano-fertilizers and their roles in sustainable agriculture. Int. J. Agric. Crop Sci., 5, 2229-2232 (2013).

Nair, R., S. Varghese, B. Nair, T. Maekawa, Y. Yoshida and S. Kumar: Nanoparticulate material delivery to plants. Plant Sci., 179, 154163 (2010).

Nasiri, Y., S. Zehtab-Salmasi, S. Nasrullahzadeh, N. Najafi and K. Ghassemi-Golezani: Effects of foliar application of micronutrients (Fe and $\mathrm{Zn}$ ) on flower yield and essential oil of chamomile (Matricaria chamomilla L.). J. Med. Plant. Res., 4, 1733-1737 (2010).

Pandey, A.C., S.S. Sanjay and R.S. Yadav: Application of $\mathrm{ZnO}$ nanoparticles in influencing the growth rate of Cicer arietinum. J. Exp. Nanosci., 6, 488-497 (2010).

Panpattee, D.G., Y.K. Jhala H.N. Shelat and R.V. Vyas: Microbial inoculants in sustainable agricultural productivity. In: Nano Particles: The Next Generation Technology for Sustainable Agriculture, Springer, New Delhi, pp. 289-300. (2016).

Panse, V.G. and P.V. Sukhatme: Statistical Methods for Agricultural Workers. ICAR, New Delhi (1985).

Paul, E.A. and F.E. Clark: Soil Microbiology and Biochemistry. Academic Press: San Diego, California, p. 188 (1996).

Rajput V.D., T. Minkina, S. Sushkova, V. Tsitsuashvili, S. Mandzhieva, A. Gorovtsov, D. Nevidomskyaya and N. Gromakova: Effect of nanoparticles on crops and soil microbial communities. J. Soils Sedim., 18, 2179-2187 (2018).

Raliya, R., V. Saharan, C. Dimkpa and P. Biswas: Nanofertilizer for precision and sustainable agriculture: Current state and future perspectives. J. Agric. Food Chem., 66, 6487-6503 (2018).
Romheld, V. and M.M. El-Fouly: Foliar nutrient application: Challenge and limits in crop production. In: Proceedings. of $2^{\text {nd }}$ International Workshop on Foliar Fertilization, pp. 1-34 (1999).

Roosta, H.R., M. Safarizadeh and M. Hamidpour: Effect of humic acid contained nano-fertile fertilizer spray on concentration of some nutrient elements in two lettuce cultivars in hydroponic system. $J$. Sci. Tech. Greenhouse Cult., 7, 51-58 (2017).

Sarkar, S., S.C. Datta and D.R. Biswas: Using nanoclay polymer composite for efficient delivery of $\mathrm{N}$ and $\mathrm{P}$ to pearl millet grown in a smectite dominant soil in a green house experiment. Clay Res., 32,102-113(2013).

Sekhon, B.S.: Nanotechnology in agri-food production: An overview. Nanotechnology, Sci. Applic., 7, 31-53(2014).

Shang, Y., M.K. Hasan, G.J. Ahammed, M. Li, H. Yin and J. Zhou: Applications of nanotechnology in plant growth and crop protection: Areview. Molecules, 24, 2558 (2019).

Shrivastava, S., P.S. Tomar, V. Arya and S.K. Verma: Effect of integrated application of inorganic and organic sources on soil properties, yield and nutrient uptake by pearl millet. Int. Q. J. Life Sci., 12, 609$614(2017)$

Singh, U., C.S. Praharaj, S.S. Singh, K.K. Hazra and N. Kumar: Upscaling nutrient energy and system productivity of pigeonpeawheat croppingsystem in Indo-Gangetic plains of India. J. Environ. Biol., 39, 647-658.(2018)

Soliman, A.S., M. Hassan, F. A. Elella, A.H.H. Ahmed and S.A.E. Feky: Effect of nano and molecular phosphorus fertilizers on growth and chemical composition of Baobab (Adansonia digitata L.). J. Plant Sci., 11, 52-60 (2016).

Tiwari, G.K., S.S. Kumar, A. Singh and Babulal: A statistical study of trends of rice-wheat production on districts of Western U.P., India. Int. J. Curr. Microbiol. App. Sci., 8, 2430-2443 (2019).

Togas, R., L.R. Yadav, S.L. Choudhary and G. V. Shisuvinahalli: Effect of integrated use of fertilizer and manures on growth, yield and quality of pearl millet. Int. J. Curr. Microbiol. Appl. Sci., 6, 25102516 (2017).

Vance, E.D., P.C. Brookes and D.S. Jenkinson: An extraction method for measuring soil microbial biomass carbon. Soil Biol. Biochem., 19, 703-707 (1987).

Wang, W., J.C. Tarafdar and P. Biswas: Nanoparticle synthesis and delivery by an aerosol route for watermelon plant foliar uptake. $J$. Nanopart. Res., 15,1-13 (2013).

Wojtkowiak, K., A. Stepien, M. Warechowska and M. Raczkowski: Content of copper, iron, manganese and zinc in typical light brown soil and spring triticale grain depending on a fertilization system. $J$. Elementol., 19, 833-844 (2014).

Wu, M.: Effects of incorporation of nano-carbon into slow released fertilizer on rice yield and nitrogen loss in surface water of paddy soil. Adva. J. Food Sci. Technol., 5, 398-403 (2013).

Xie, Y., J. Fan, W. Zhu, E. Amombo, Y. Lou, L. Chen and J. Fu: Effect of heavy metals pollution on soil microbial diversity and bermudagrass genetic variation. Front. Plant Sci., 7, 755 (2016).

Zain, M., I. Khan, R.W.K. Qadri, U. Ashraf, S. Hussain, S. Minhas, A. Siddique, M. Jahangir and M. Bashir: Foliar application of micronutrients enhances wheat growth, yield and related attributes. Am. J. Plant Sci., 6, 864-869 (2015).

Zulfiqar F, M. Navarro, M. Ashraf, N.A. Akram, S. Munné-Bosch: Nanofertilizer use for sustainable agriculture: Advantages and limitations. Plant Sci., 289, 110270 (2019). 